\title{
Impact of drought on the productivity of agricultural crops within the Oltenia Plain, Romania
}

\author{
Irina Ontel $\mathrm{A}^{\mathrm{A}^{*}}$, Alina Vladut ${ }^{\mathrm{B}}$ \\ Received: October 11, 2014 | Revised: January 27, 2015 | Accepted: February 26, 2015
}

\begin{abstract}
The purpose of this study was to evaluate the effect of moisture conditions on the productivity of agricultural crops within the Oltenia Plain, Romania at various time scales. The agro-databases contain the productions of winter wheat, maize and sunflower reported by the National Institute of Statistics and Agricultural Department for the period 1971-2013. The meteorological elements used were represented by the rainfall amount and air-temperature recorded at the six meteorological stations: Drobeta-Turnu Severin, Calafat, Băilești, Bechet, Craiova, Caracal and Turnu-Magurele. According to the SPI and De Martonne Index, the driest years, with low rainfall amounts, were 1983-1985, 1993, 2000, 2002, 2007 and 2012, with different degrees of water deficit. Moreover, the years with the lowest productions were recorded in the last half of the analysed period: 1993, 1996, 2000, 2002, 2007 and 2012. The impact of the drought variability of yield on the agricultural crops was evaluated using Bravais-Pearson correlations test, which was statistically significant in the last half of the reference period, while the correlation in the first half of the period it was not statistically significant. This result can be explained by the political system and the gradual degradation of the irrigation system, which determined the addiction on climatic conditions after ' 89 years.
\end{abstract}

Key words: drought, SPI, De Martonne Index, crops yield, Oltenia Plain, Romania.

\section{Introduction}

Climate change manifests through increasing average temperature and changing rainfall regime and it has many negative effects, both globally and regionally. The study of drought is very important in terms of the potential impact on the environment, economy and food security. According with Lobell, et al. (2011), changes in temperature have caused reduction in global yields of maize and wheat by 3.8 and $5.5 \%$ respectively from 1980 to 2008 . This was relative to a counterfactual without climate change. WMO asserts that between 1976 and 2006 the number of areas and people affected by droughts went up by almost $20 \%$. In 2003 , Europe experienced its warmest summer since the records began, resulting in about $€ 12$ billion in economic losses and $€ 1.5$ billion in 2007 , in Greece, Moldava and the rest of the Southeastern Europe. Crop failure was widespread, forest fires raged and tourists deserted holiday spots in droves, put off by water restrictions, scorched landscapes and record temperatures (Demuth, 2009).

In Europe, many studies about the impacts of climate on agriculture have been made in the last decade (Olesen, Bindi, 2002; Parry, et al., 2004; Rounsevell, et al., 2005; Maracchi, et al., 2005; Berry, et al., 2005; Iglesias, et al., 2009, 2011; Potop, 2011; Holzkämper, et al., 2011; Gobin, 2012). All these studies and Climate Crop model, which estimates the combined effects of projected changes in temperature, rainfall as well as $\mathrm{CO}_{2}$ concentration across Europe, consider-

\footnotetext{
A University of Bucharest, Faculty of Geography, Nicolae Bălcescu Av., No.1, postcode 010041, sect.1, Bucharest, Romania

B University of Craiova, Departament of Geography, St. A. I. Cuza, No.13, postcode 200585, Craiova, Romania

* Corresponding author: Ontel Irina, e-mail: ontel.irina@yahoo.com
} 


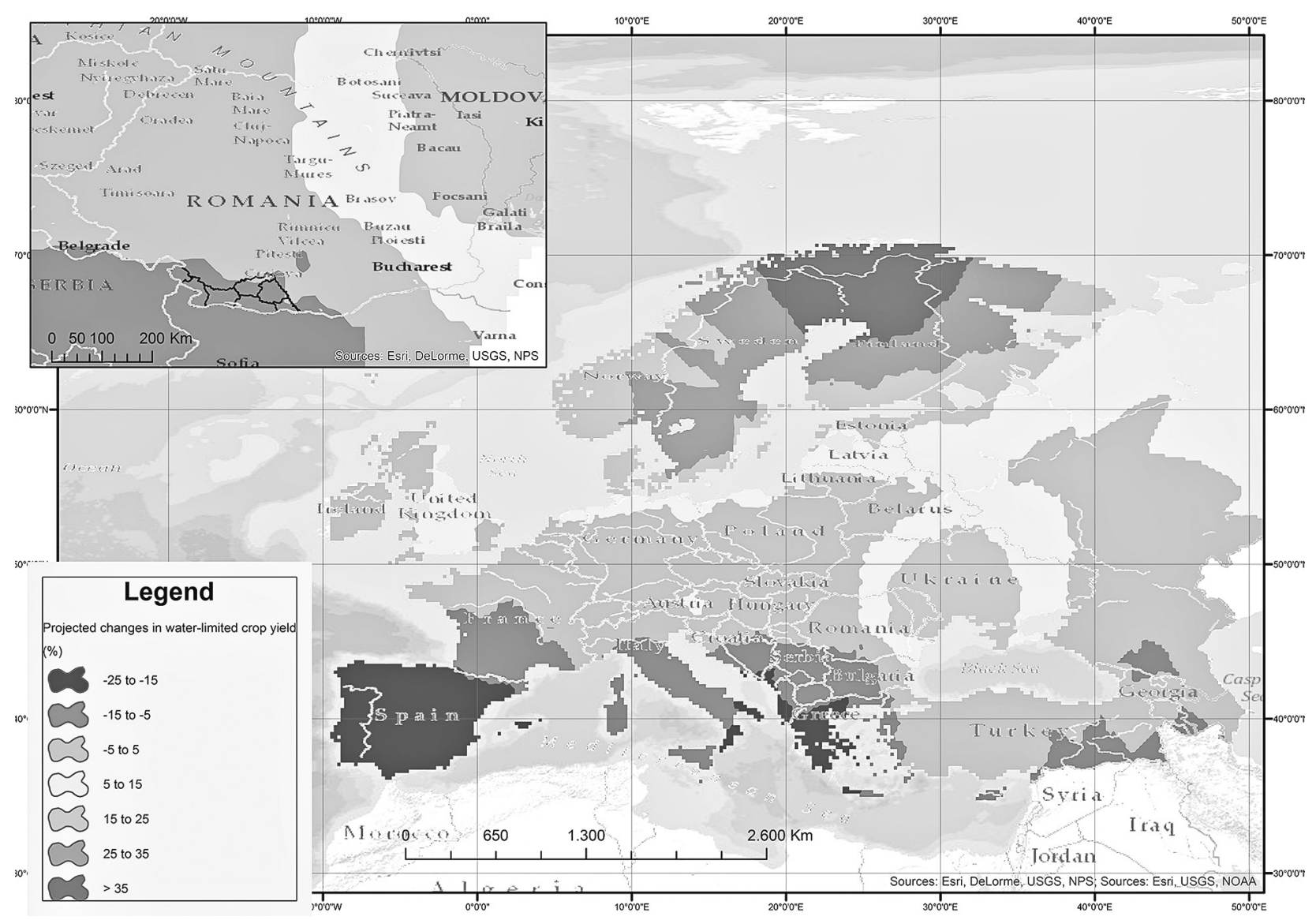

Figure 1. Projected changes in water-limited crop yield Source: Internet 1

ing certain management changes thus incorporating effects of adaptation (European Environment Agen$c y, 2014)$, confirm that the cereal productivity trends are increasing in north-western Europe, in Scandinavia and decreasing in the Mediterranean region and south-eastern Europe, which will require adaptation to new climatic conditions (Figure 1). According to IPCC WGII AR5, 2014, there is medium confidence that climate trends have negatively affected wheat and maize production for many regions (medium evidence, high agreement). There is also high confidence that warming has benefitted crop production in some high-latitude regions, such as Northeast China or the United Kingdom (Jaggard, et al., 2007, Supit, et al., 2010; Chen, et al., 2010; Gregory, Marshall, 2012, cited by IPCC WGII AR5, 2014).

In Romania, the impact of climate on the agriculture was studied by Sandu et al., 2010, Mateescu and Alexandru, 2010, which show that the winter wheat can benefit from the interaction between increased $\mathrm{CO}_{2}$ concentrations and higher air temperatures, while maize is vulnerable to climate change, mainly in the case of a scenario predicting hot and droughty conditions. According the ClimateCrop model for the 2050 s compared with 1961-1990 for 12 different climate models projections under the $\mathrm{A} 1 \mathrm{~B}$ emission scenario (Figure
1), in the South of Romania, there have been projected changes in water-limited crop yield, between -5 and $5 \%$ in the south-eastern part of the country and between -5 and $-15 \%$ in the south-western part.

This paper presents the impact of drought on the crop yield within Oltenia Plain, which was observed between two political periods, 1971-1989 and 19902013. The changes of the political system after ' 89 determined the appearance of some negative effects like fragmentation of farming land and degradation of irrigation systems, which made the crops more vulnerable to drought phenomenon.

\section{Methods and data}

There are many methods for quantify the drought phenomenon - Palmer Drought Severity Index (Palmer, 1965), Crop Moisture Index (Palmer, 1968), Deciles (Gibbs, Maher, 1967), Percent of normal (Willeke, et al., 1994), Standardized Precipitation Index (McKee, et al., 1993), which have a high or low degree of complexity. In this study, there were used Standardized Precipitation Index (SPI) and Aridity Index of E. de Martonne (IM), based on precipitation and temperature data registered at seven weather stations (Calafat, Bailesti, Bechet, Turnu Magurele, Caracal, Craiova and D.T.Severin) from 


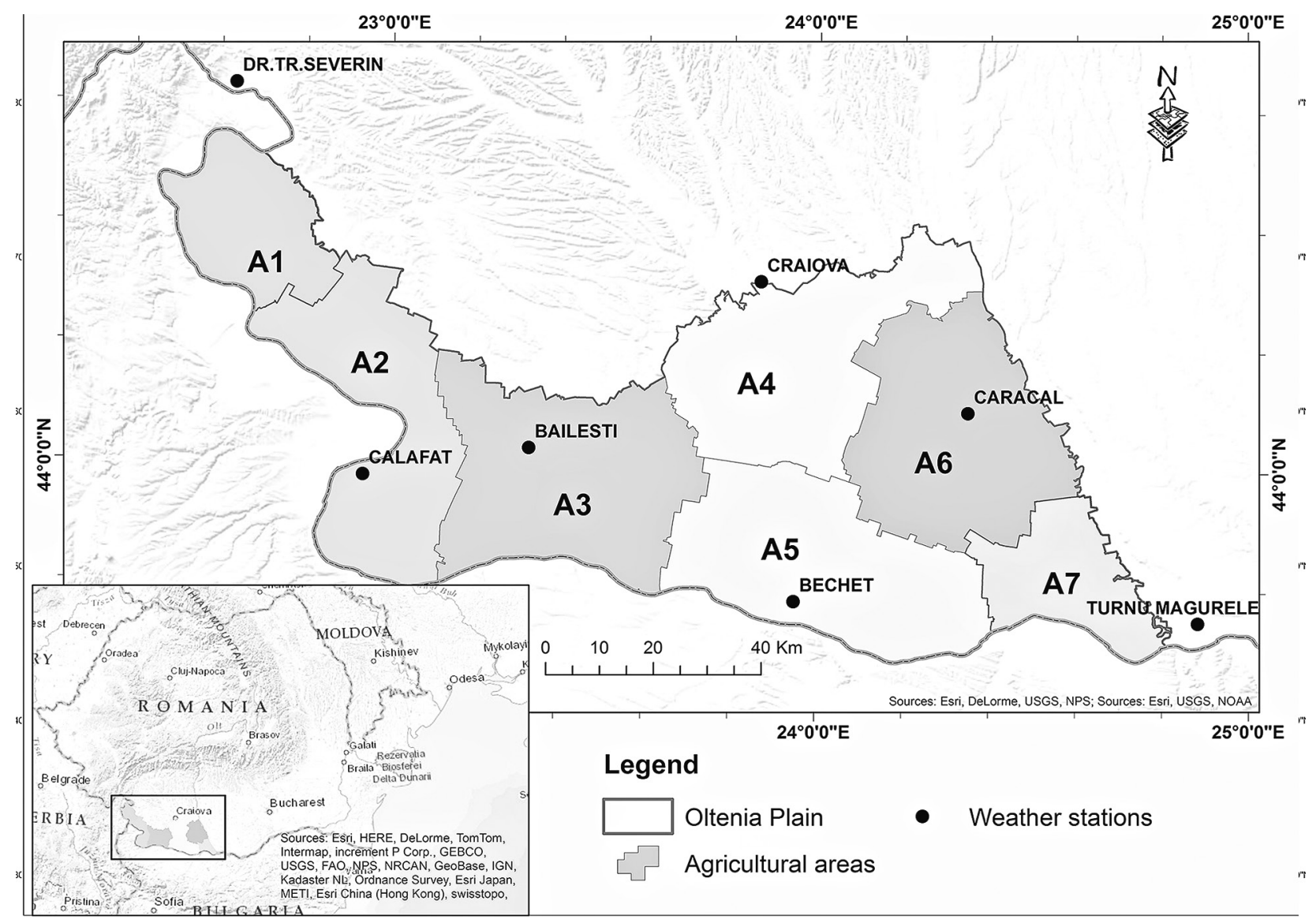

Figure 2. The agricultural regions within Oltenia Plain, Romania

1961 to 2013. According to the distance between the administrative territorial units (ATU) and weather stations, there were delineated seven agricultural subregions (Figure 2, Table 1) and it was calculated the crops yield for each subregion in order to establish the relationship between climate conditions from each weather station and the crops yield. The agricultural data sets are represented by winter wheat $\&$ rye (the values are cumulated), maize and sunflower reported by the $\mathrm{Na}$ tional Institute of Statistics (1971-2004) and Agricultural Department for the period 2005-2013. Landsat images were used to calculate NDVI, which show the vegetation growth in the dry years.

Table 1. The agricultural regions and the weather station within Oltenia Plain

\begin{tabular}{|l|c|l|}
\hline Region & No. ATU & Weather station \\
\hline A1-D.T.Severin & 7 & D.T.Severin \\
\hline A2-Calafat & 16 & Calafat \\
\hline A3-Bailesti & 24 & Bailesti \\
\hline A4-Craiova & 25 & Craiova \\
\hline A5-Bechet & 19 & Bechet \\
\hline A6-Caracal & 29 & Caracal \\
\hline A7-Turnu Magurele & 11 & Turnu Magurele \\
\hline
\end{tabular}

The Standardized Precipitation Index (SPI) is one of the most commonly used indicators of meteorological drought monitoring (McKee, et al. 1993; Hayes, et al., 1999; Paltineanu, 2008; Potop, 2011), which can be established for each time scale (1, 3, 6, 12 months, etc.).

According with Edwards, McKee, 1997, the SPI involves fitting a gamma probability density function to a given frequency distribution of precipitation totals for a climate station. The gamma distribution is defined by its frequency or probability density function:

$$
g(x)=\frac{1}{\beta^{\alpha} \Gamma(\alpha)} x^{\alpha-1} e^{-x / \beta} \text { for } x>0
$$

where $\alpha$ is a shape parameter $(\alpha>0), \beta$ is a scale parameter $(\beta>0), x$ is the precipitation amount $(x>0)$, and

$$
\Gamma(\alpha)=\int_{0}^{\infty} y^{\alpha-1} e^{-y} d y
$$

where $\Gamma(\alpha)$ is the gamma function. The $\alpha$ and $\beta$ parameters of the gamma probability density function are estimated for each station, for each time scale of interest ( 3 months, 12 months, 48 months, etc.), and for each month of the year. Edwards \& McKee (1997) suggest estimating $\alpha$ and $\beta$ using the maximum likelihood solutions of Thom (1966): 


$$
\begin{aligned}
& \hat{\alpha}=\frac{1}{4 A} 1+\sqrt{1+\frac{4 A}{3}} \\
& \hat{\beta}=\frac{\bar{x}}{\hat{\alpha}}
\end{aligned}
$$

where:

$$
A=\ln (\bar{x})-\frac{\sum \ln (x)}{n}
$$

$n=$ number of precipitation observations

The resulting parameters are then used to find the cumulative probability of an observed precipitation event for the given month and time scale for the station in question. The cumulative probability is given by:

$$
G(x)=\int_{0}^{x} g(x) d x=\frac{\hat{\imath}_{\hat{\beta}}^{\hat{\alpha} \Gamma(\hat{\alpha})}}{\int_{0}^{x}} x^{\hat{\alpha}-1} e^{-x / \hat{\beta}} d x
$$

In this study, to calculate Standardized Precipitation Index it was used the program SPI_SL_6.exe, compiled in $\mathrm{C}++$, available at Internet 2.

Table 2. Classification scale for SPI values (after McKee, 1993)

\begin{tabular}{|c|l|c|}
\hline SPI Values & $\begin{array}{l}\text { Drought } \\
\text { Category }\end{array}$ & $\begin{array}{c}\text { Time in Category } \\
(\%)\end{array}$ \\
\hline-0.99 to 0 & Normal & $\sim 24$ \\
\hline-1.00 to -1.49 & Moderate drought & 9.2 \\
\hline-1.50 to -1.99 & Severe drought & 4.4 \\
\hline$\leq-2.00$ & Extreme drought & 2.3 \\
\hline
\end{tabular}

The weakness of the SPI is that it is based only on precipitation. Therefore, in this study it was used Aridity Index of E. de Martonne (IM) based on both temperature and precipitation (Dumitrascu, 2006; Paltineanu, 2007; Vladut, 2010; Dumitrescu, 2012; Pravalie, et al., 2013), $\mathrm{IM}_{\text {monthly }}=12^{*} \mathrm{Pi} /(\mathrm{Ti}+10)$, where, $\mathrm{Pi}$ is the monthly precipitation amount $(\mathrm{mm})$ and $\mathrm{Ti}\left({ }^{\circ} \mathrm{C}\right)$ is the respective mean monthly air-temperature and for summer season, $\mathrm{IM}_{\text {summer }}=\left(\mathrm{IM}_{\mathrm{VI}}+\mathrm{IM}_{\mathrm{VII}}+\mathrm{IM}_{\mathrm{VIII}}\right) / 3$. IM is used for determination of irrigation demand, the supplement irrigation water becomes necessary when IM < 20 (WMO, 1975 and Nastos, et al., 2013 cited by Shahabfar, Eitzinger, 2013).

The Normalized Difference Vegetation Index (NDVI) is the most used remote sensing index for monitoring the vegetation growth (Rouse, et al. 1974; Gitelson, 2012; Julien, 2006; Sonnenschein, et al., 2011) and is defined as: $(\rho$ NIR- $\rho$ RED) / $(\rho$ NIR $+\rho$ RED), where $\rho$ NIR is the reflectance of the vegetation in near-infrared and $\rho$ RED is the reflectance of the veg- etation in red. The Landsat images are available at Internet 3 .

\section{Results and discussion}

\section{Assessment of the drought during the vegetation period of crops}

To highlight the drought event for growing crops period it was calculated the Standardized Precipitation Index (SPI) for 12-months (the end of September), 8-months (the end of May) and 5-months (the end of August). Besides, the De Martonne Index was calculated for the summer season because in this period high temperature determine increase of the evapotranspiration, which has a negative impact on the crops yield of the maize and sunflower.

As results, the $\mathrm{SPI}_{12}$ registered the lowest values in 1993, between -3.24 (Caracal station) and -1.23 (Drobeta Turnu-Severin station); at all meteorological stations it was registered extreme drought, except D.T. Severin, where it was moderate drought (Figure 3). Other years with extreme drought were 1974 (only at Turnu Magurele, -2.02), 1985 (Bechet, -2.27 and Turnu Magurele -2.16) and 1992 (-2.39 at Bailesti, -2.32 at Calafat and -2.17 at D.T. Severin), and severe drought it was registered in 1974, 1990, 1992, 1993 and 2002 (Figure 3). The $\mathrm{SPI}_{12}$ values show that extreme drought was $2-4 \%$ from 52 years (1962-2013), severe drought $2 \%$, moderate drought $10-11 \%$ at all meteorological stations and more than $65 \%$ were normal years.

The $\mathrm{SPI}_{8}$ values (the end of May), show that the lowest values were recorded in 2002 (Craiova, -3.61; D.T. Severin, -3.55; Calafat, -3.21), exceeding the $\mathrm{SPI}_{8}$ and $\mathrm{SPI}_{12}$ values from 1993. This situation is reflected on the production of wheat and rye from both years; therefore, in 2002, the production was less than in 1993. Severe and extreme drought was indicated by $\mathrm{SPI}_{8}$ in 1968, 1983, 1985, 1992, 2001 and 2007 (Figure 4). The frequency of the drought events is higher in the south-western part of Oltenia Plain (17.3\% at Calafat and Bailesti) than in the north (13.5\% at Craiova) and west (11.5 \% at D.T.Severin). In the same time, normal years were recorded more than $70 \%$ at D.T.Severin (76.9\%), Craiova (73.1\%) and Calafat (71.2 \%) and between $63.5 \%$ and $67.3 \%$ at Bailesti, Bechet, Turnu Magurele and Caracal.

The assessment of the $\mathrm{SPI}_{5}$ values (the end of August) is very important for maize and sunflower. The vegetation period of these crops starts at the beginning of April and ends at the end of August. So, the values of $\mathrm{SPI}_{5}$ reveal the extreme drought in 2000 (-2.72 at Caracal, -2.44 at Turnu Magurele and -2.07 at Craiova) and in 1993 at the Craiova station and Caracal (-2.63 and respectively -2.53$)$. The severe drought 


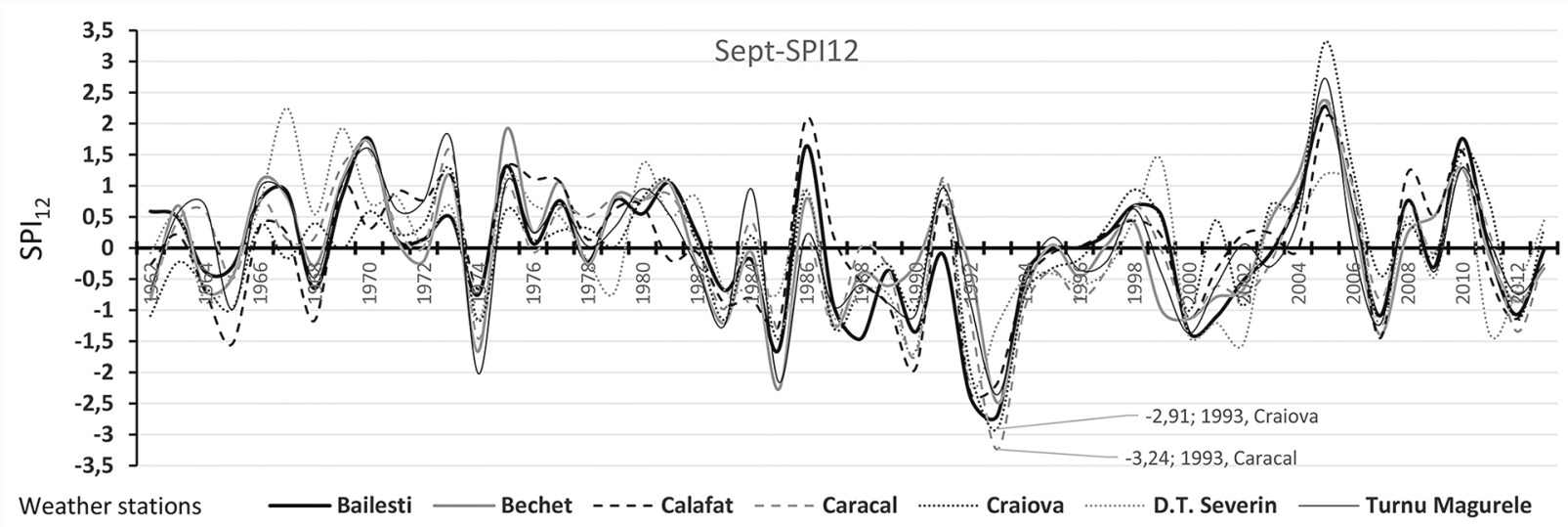

Figure 3. Standardized Precipitation Index for 12 months (Oct. - Sept.)

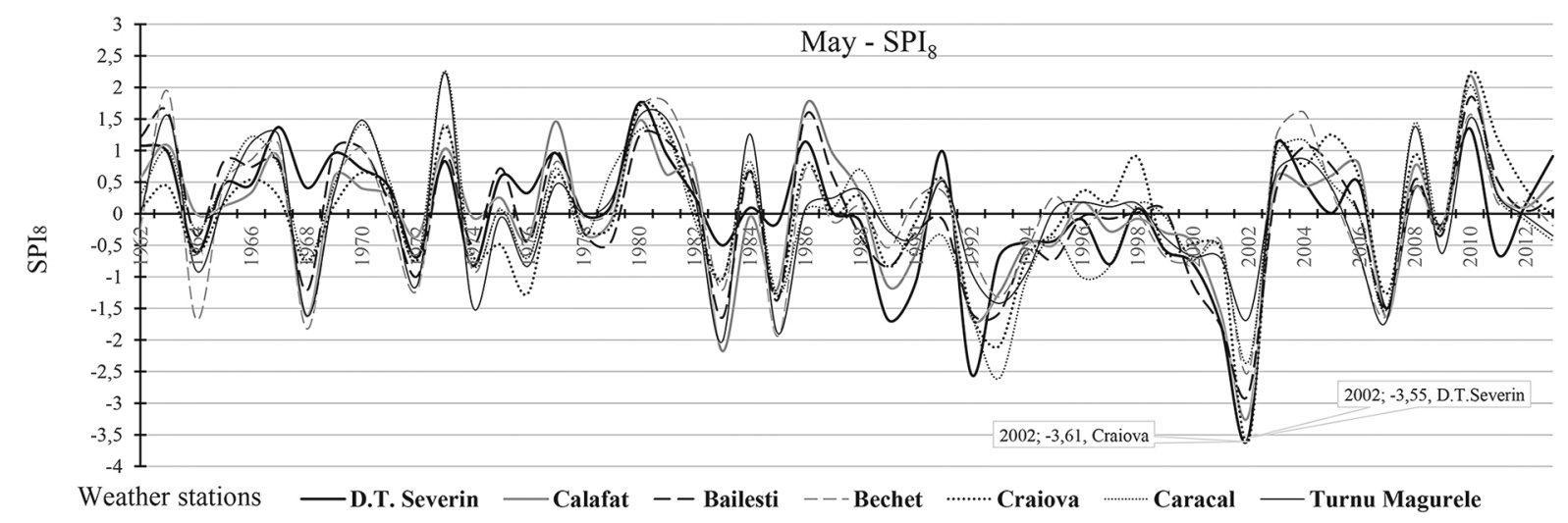

Figure 4. Standardized Precipitation Index for 8 months (Oct. - May)

was registered in 1962, 1988, 1993, 1996 and 2000 (Figure 5). The percentage of drought years in the southwestern part of Oltenia Plain is greater than the eastern part (15-17\% at D.T.Severin, Calafat, Bailesti and Bechet and $11.3-13.2 \%$ at Craiova, Caracal and Turnu Magurele).

Other important climatic parameter during the vegetation period of the maize and sunflower along with precipitation amount, is temperature. So, it was calculated the De Martonne Index ( $\left.\operatorname{IM}_{\text {summer }}\right)$ for three months (June, July and August) in order to iden- tify the period when the crops require water from irrigation systems, evapotranspiration surpassing the water from precipitation. For example, July 2007 was an extremely dry month, not only due to the decrease of the precipitation amount but also as a result of high temperature (Sandu, et al, 2010; Ontel, Morosanu, 2014). The temperature trends in summer increased between 1961 and 2010 and the trends are statistically significant (more than 99\% confidence level) at all meteorological within Oltenia Plain (Vladut, Ontel, 2013). Therefore, $\mathrm{IM}_{\text {summer }}$ registered the lowest values

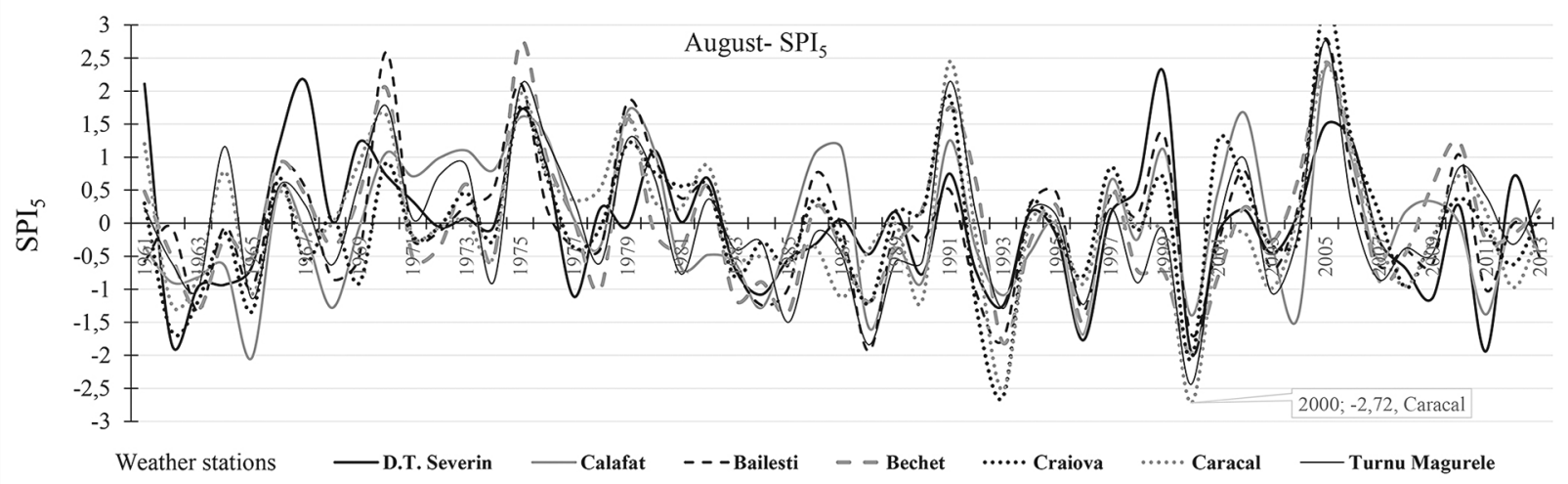

Figure 5. Standardized Precipitation Index for 5 months (Apr.- Aug.) 


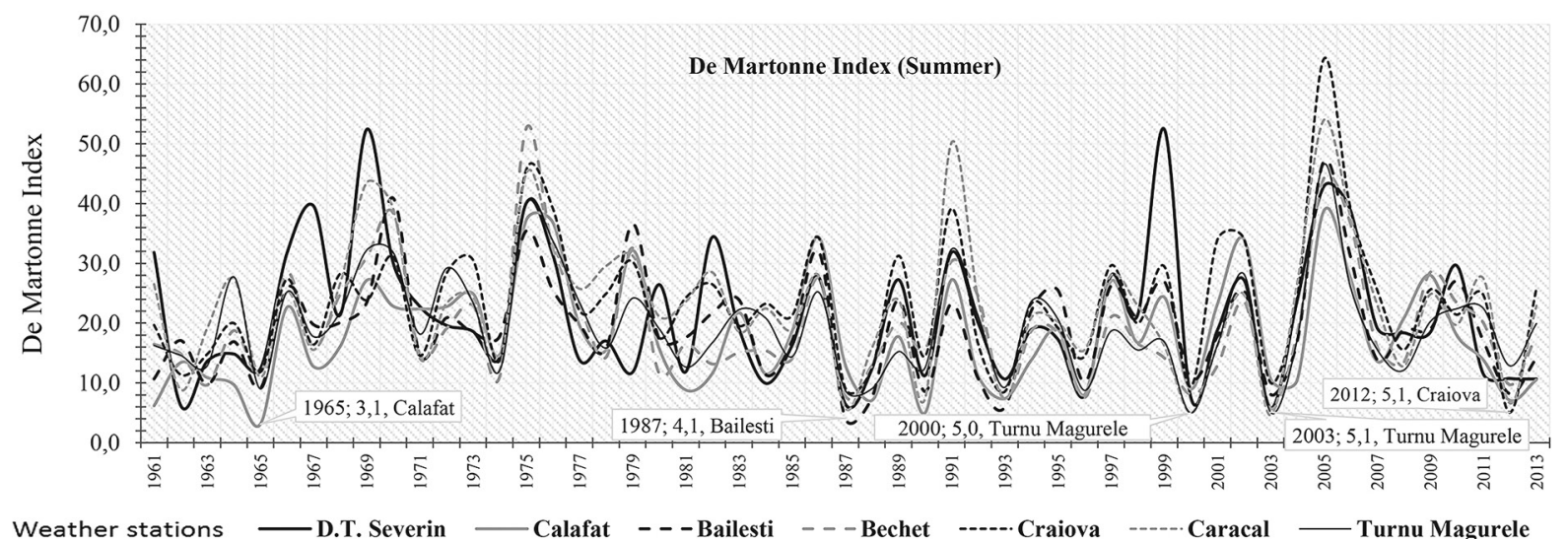

Figure 6. De Martonne Index for the summer season

in 1965 (3.1, Calafat), 1987 (4.1, Bailesti), 2000 and 2003 (Turnu Magurele, 5.0 and 5.1) and 2012 (Craiova 5.1) (Figure 6).

\section{Assessment of the impact of drought on the crops yield}

Between 1971 and 2013, the crop yield within the Oltenia Plain has been influenced by many factors (social, political, economic and climatic). In terms of political system, it can be distinguished two periods: the communist (1971-1989) and the post-communist period (1990-2013). In the first period, the crop production was less vulnerable to the climatic factors and the trend of the crop yield was an increasing one. According to Fraseer, Stringer (2009), and Stringer, Harris (2013) productivity was maintained through the irrigation systems, intensive fertiliser application and the plantation of shelterbelts. In the second period, the relationship between crop production and climatic conditions was closer; therefore in the post-communist period, vegetation was more vulnerable to the climatic factors than in the first period.
The wheat and the rye (Figure 7) registered, between 1990 and 2013, the lowest productions in 2002 and $2007(<1,000 \mathrm{~kg} / \mathrm{ha}$ for all agricultural areas, 283 $\mathrm{kg} / \mathrm{ha}$ at the Bailesti region, $401 \mathrm{~kg} / \mathrm{ha}$ at the Craiova region, $449 \mathrm{~kg} / \mathrm{ha}$ at the Calafat region, etc.); values below the mean were also recorded in 1993, 1996, 2000, 2003 and 2012. The productivity has been decreasing between 1990 and 2013; however, the dependence coefficient of the linear trends have been statistically insignificant $\left(R^{2}=0.16\right.$ within Caracal region, $R^{2}$ $=0.13$ within Turnu Magurele region, $\mathrm{R}^{2}=0.05$ within Bechet region, $\mathrm{R}^{2}=0.02$ Bailesti and very close by o within Craiova and D.T.Severin regions), (Figure 7). Observing the variability of the wheat and rye yield (Figure 7) and the $\mathrm{SPI}_{8}$ (Figure 4), it can be assumed that the lowest productions were registered in drought years 1993, 2002, 2007, except 1996 when the wheat productions had low values $(\sim 1,500 \mathrm{~kg} / \mathrm{ha})$ even if the values of $\mathrm{SPI}_{8}$ were between 1 and -1 at all the meteorological stations. In 2002, the wheat productivity decreased with 54.1\% than 1998 (normal year according $\mathrm{SPI}_{8}$ ) and with $48.9 \%$ than mean of the post-com-

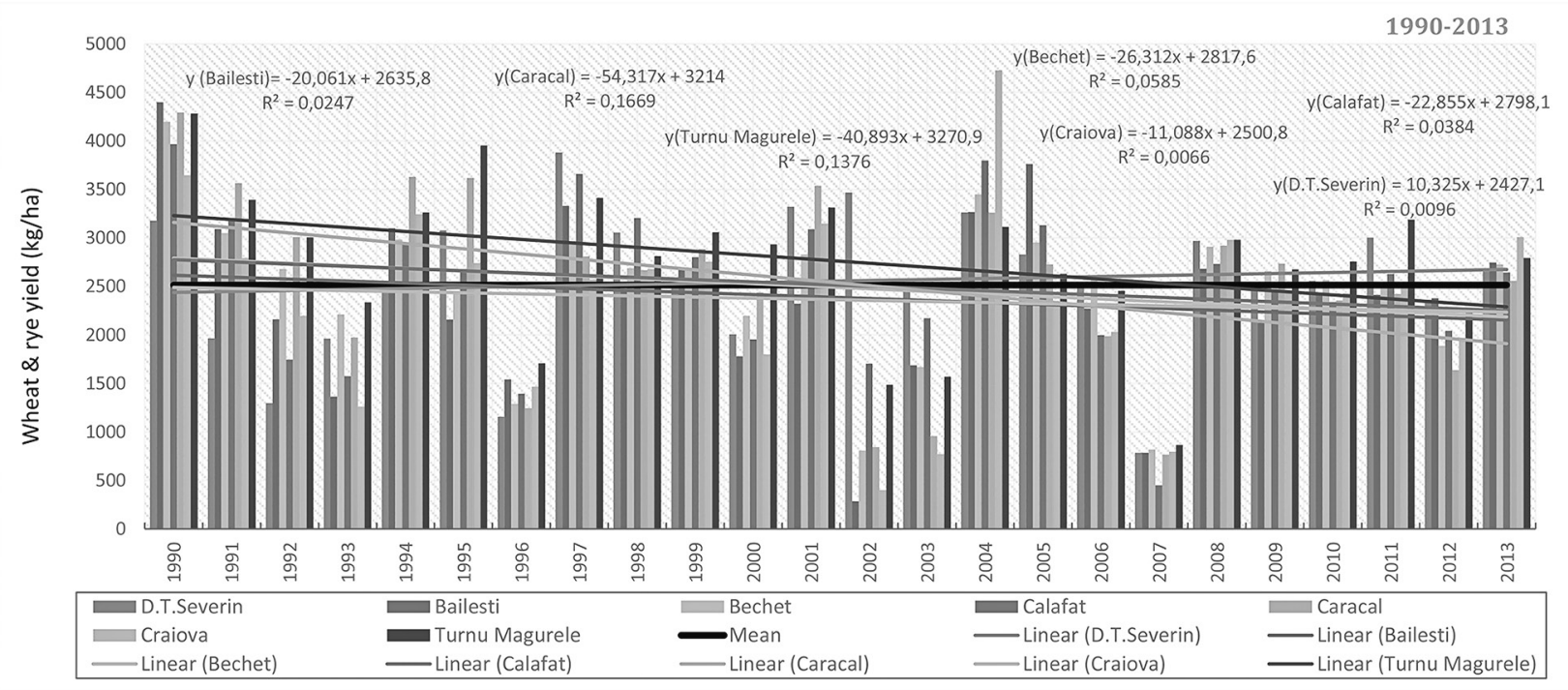

Figure 7. The wheat and rye yield within Oltenia Plain (1990-2013) 
munist period. In 1993, it decreased with $27.9 \%$ than mean and in 2007 with $70 \%$ than mean and with 66.7 $\%$ than 2006 (normal year according SPI $_{8}$ value).

Significant relationships were found between wheat \& rye yield and the $\mathrm{SPI}_{8}$ values (Table 3 ) in post-communist period, $r=0.578$ for Bailesti and $r=0.517$ for Bechet, which according to Bravais-Pearson test correlations are significant at the 0.01 level and for Craiova and Calafat the correlations are significant at the 0.05 level, while in the communist period the correlations were statistically insignificant. Therefore, wheat was more vulnerable to drought in last twenty four years than in the first period.

The maize and sunflower yields are significantly different between the 1971-1989 and 1990-2013 periods; the mean of the first period was $3,900 \mathrm{~kg} / \mathrm{ha}$ for maize and $1,700 \mathrm{~kg} / \mathrm{ha}$ for sunflower, while the second was $3,100 \mathrm{~kg} / \mathrm{ha}$ for maize and $1,250 \mathrm{~kg} / \mathrm{ha}$ for sunflower, which means that the yield of the two crops has decreased. As in the case of wheat and rye, the variability of maize (Figure 8) and sunflower (Figure 9) yield, from 1990 to 2013 was influenced by climatic conditions, especially by drought. Therefore, the maize registered production less than 1,000 kg/ha in 1993 (202.4 kg/ha within Turnu Magurele region, $290.2 \mathrm{~kg} /$ ha within Bailesti region, between 313 and $350 \mathrm{~kg} / \mathrm{ha}$ within D.T.Severin, Calafat and Craiova and $888 \mathrm{~kg} /$ ha), 2000 (325.6 kg/ha within Craiova region, 500-600 $\mathrm{kg} / \mathrm{ha}$ Turnu Magurele, Caracal and Bailesti and 8oo$900 \mathrm{~kg} / \mathrm{ha}$ D.T. Severin and Bechet), 2002 (the values have been between 275 and $832 \mathrm{~kg} / \mathrm{ha}$ ) and 2007 (200-590 kg/ha). In those years, the maize yield de-

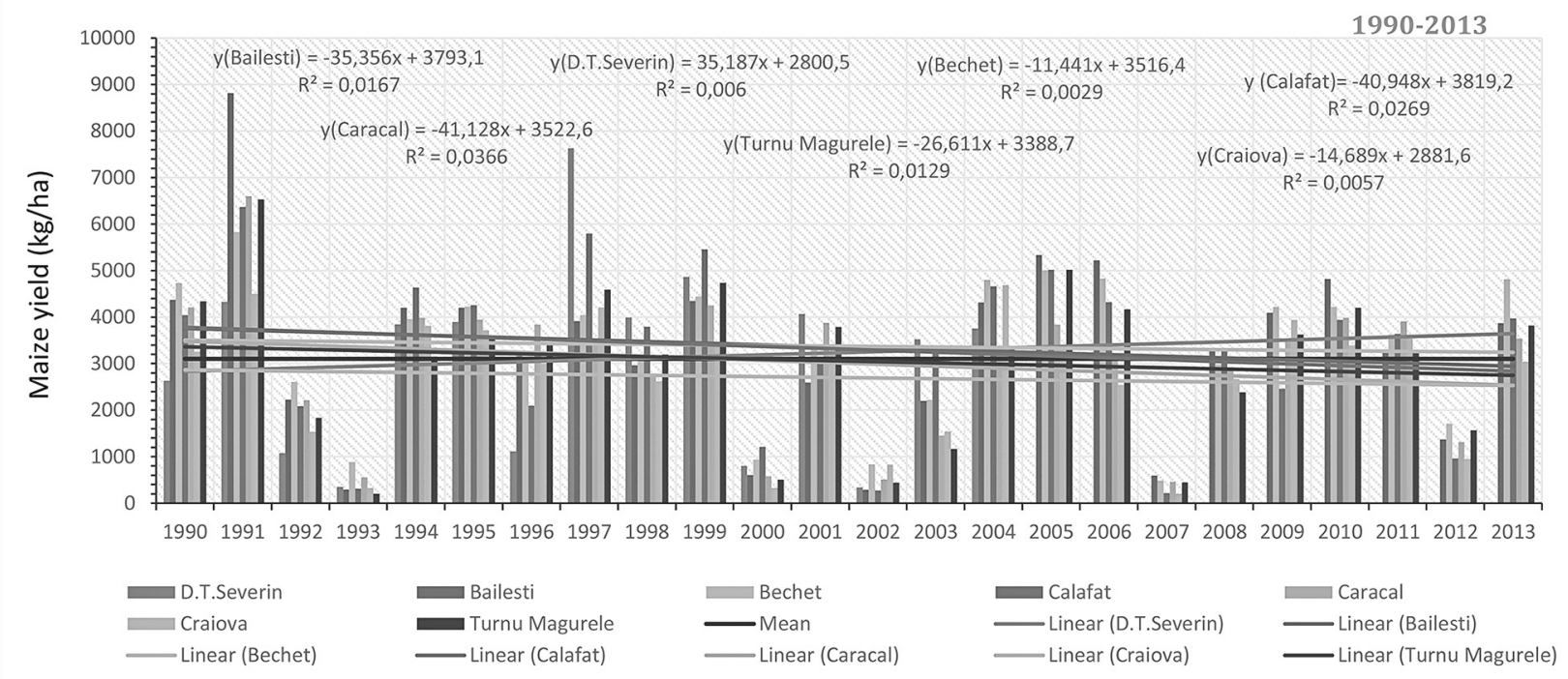

Figure 8. The maize yield within Oltenia Plain (1990-2013)

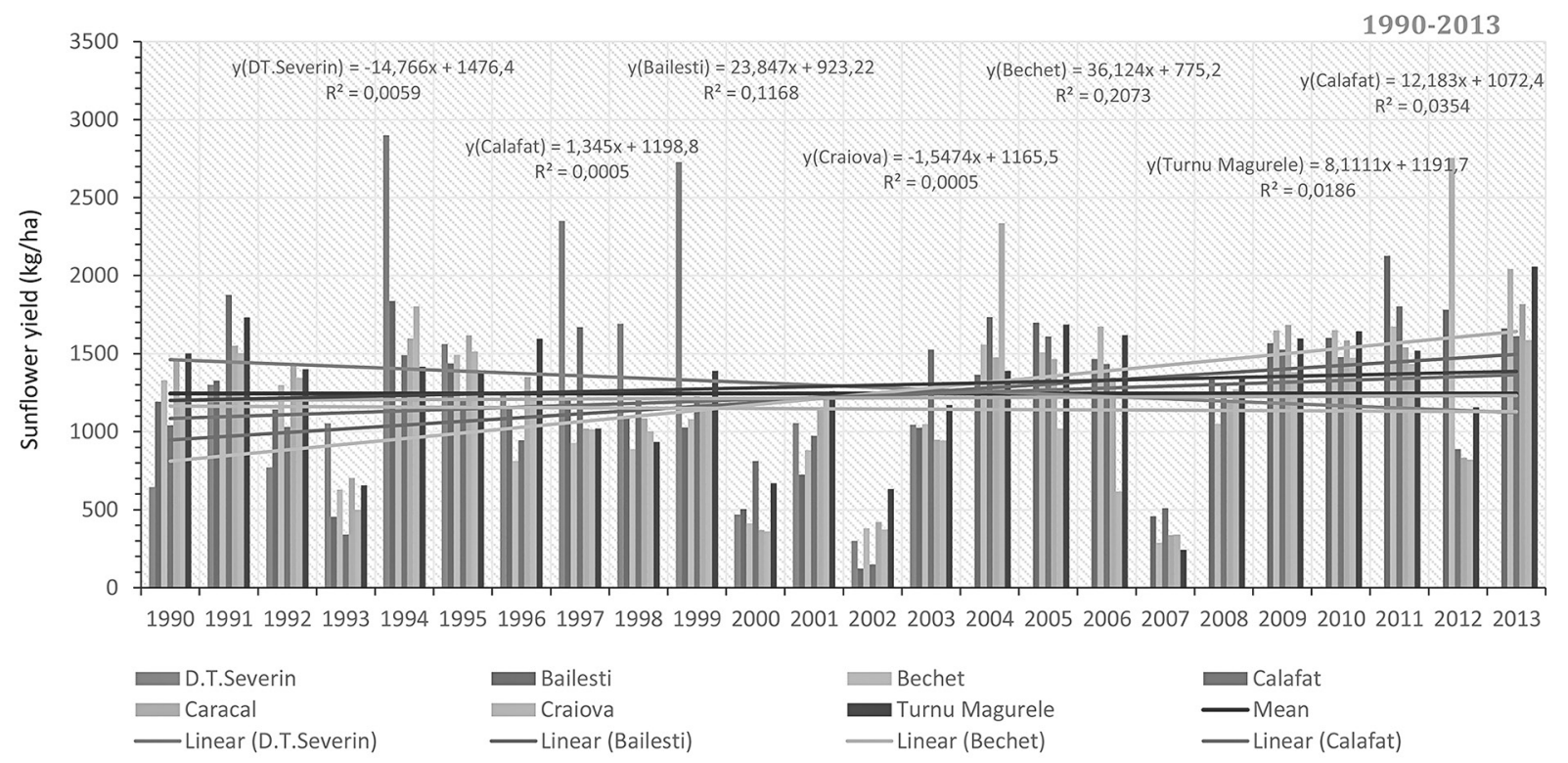

Figure 9. The sunflower yield within Oltenia Plain (1990-2013) 

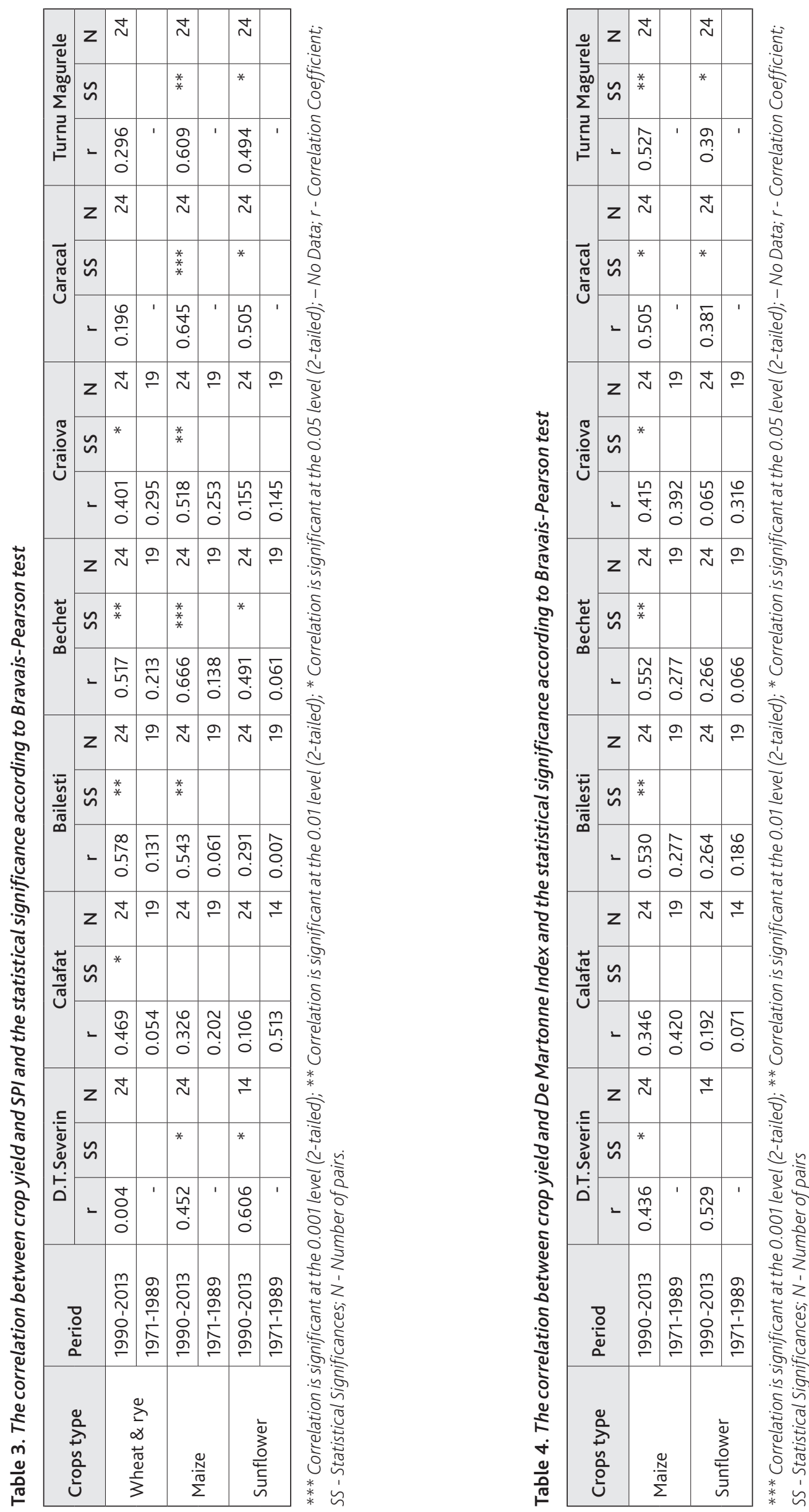


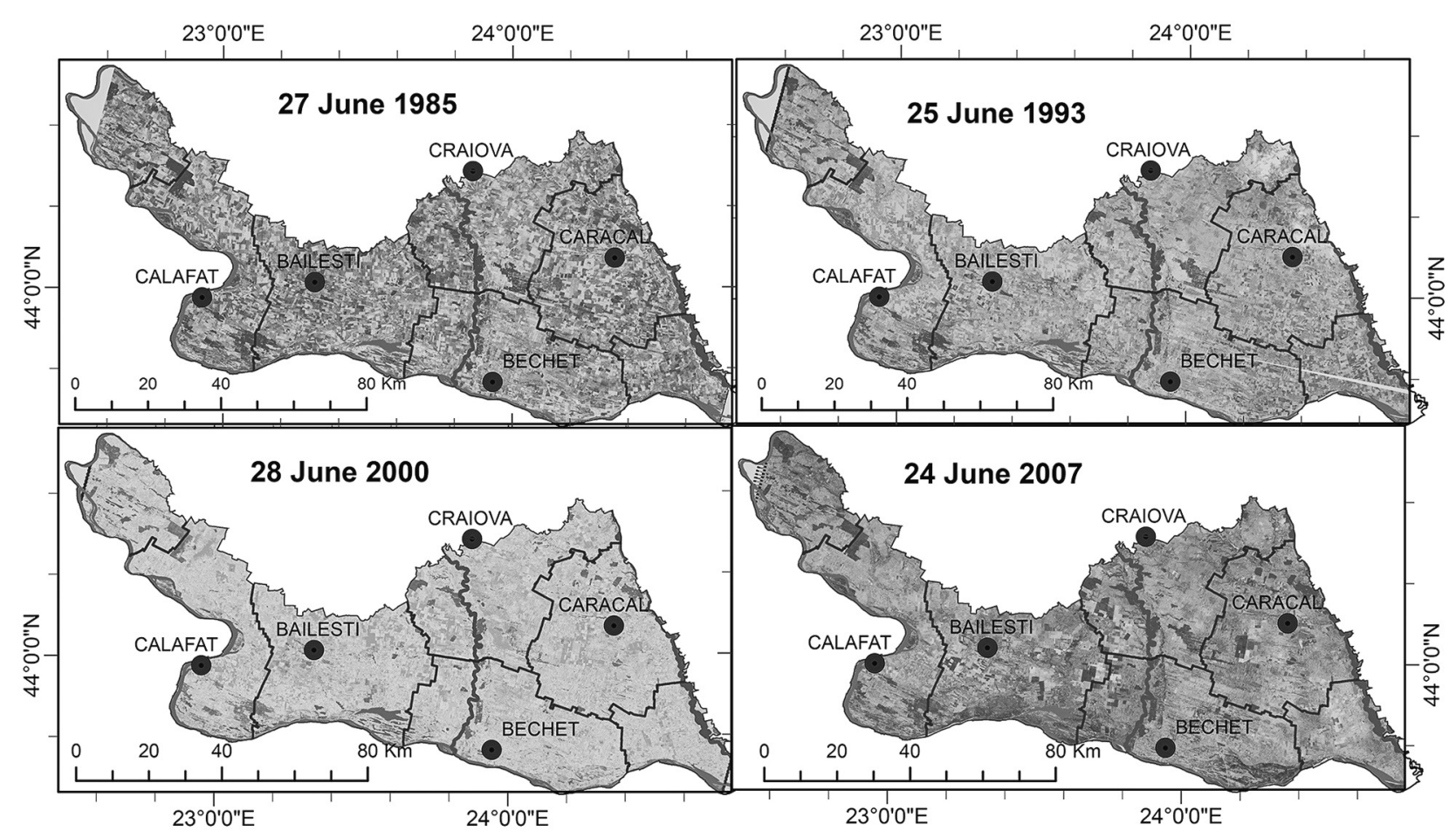

Legend

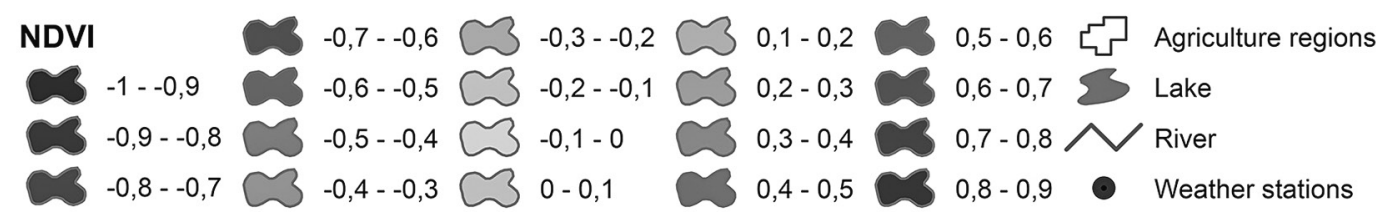

Figure 10. The Normalized Difference Vegetation Index from Landsat within Oltenia Plain

creased with respect to the mean of the period (19902013), with $77 \%$ in 2000, $83.8 \%$ in 2002, 86.5\% in 1993 and $87 \%$ in 2007 .

The correlations between maize yield and $\mathrm{SPI}_{5}$ for 1990-2013 were significant at the 0.001 level, $r=0.666$ at Bechet, $r=0.645$ at Caracal, significant at the 0.01 level, $r=0.609$ at Turnu Magurele, $r=0.543$ Bailesti, 0.518 at Craiova, while for 1971-1989 period, the correlations were statistically insignificant according to Bravais-Pearson test (Table 3).

Analyzing the correlations between maize yield and De Martonne Index it has been observed that the correlation coefficients were lower than in the first case, which means that precipitation plays a greater role in the variability of maize yield than temperatures (Table 4).

The sunflower yield decreased by $50.2 \%$ in $1993,58.7$ $\%$ in 2000, $72.7 \%$ in 2002 and $70.8 \%$ in 2007 (Figure 9). The correlation between $\mathrm{SPI}_{5}$ and sunflower yield for 1990-2013 period was significant at the 0.05 level, while for 1971-1989 period the correlation was statistically insignificant (Table 3). The values of the correlation coefficient for the De Martonne Index and sunflower were statistically significant only for Caracal and Turnu Magurele, at the 0.05 level (Table 4).
The Normalized Difference Vegetation Index values vary between -1 and +1 . According to Weier, Herring (2000), very low values of NDVI (0.1 and below) correspond to barren areas of rock, sand, or snow and moderate values represent shrub and grassland (0.2 to 0.3 ), while high values indicate temperate and tropical rainforests (o.6 to o.8) (Internet 4). The NDVI shows the low density of vegetation in dry years (Figure 10), particularly in 2000, when there have been registered values between - 0.2 and 0.1 , which confirm the decrease of the maize and sunflower production in this year. The values of NDVI in 1985, 1993 and 2007 were higher than in 2000, these ranging from 0.2 to 0.6 in 1985, 0 to 0.2 in 1993 and 0.2 to 0.4 in 2007. According to Landsat images, vegetation in the dry years after ' 89 was affected throughout the plain whatever the type of soil or regional socio-economic conditions.

\section{Conclusion}

The assessment of the variability of drought phenomenon at different time scale shows that the frequency of dry years was higher from 1983 to 2002, in the rest of the period predominating positive values of precipitation amounts. However, the upward trends of air-tem- 
peratures determined the intensification of dry periods in the last decade and increased the demand for water in agriculture, which according to the climatic model by the 2050 s the mean relative changes in water-limited crop yield within Oltenia Plain, will be between -15 to $-5 \%$, due to temperature increase.

Drought is the most important climatic factor influencing crop growth and yield. Vulnerability of crops increased in the last 24 years due to the political and socio-economic conditions, which lead to the degradation of the irrigation system and fragmentation of crops. It was found that the crop yield decreased by $50-70 \%$ in the dry years of the post-communist period, while in 1971-1989 period, there were observed upward trends, the production decrease being statistically insignificant.

The relationships between dry years and crop yield were statistically significant according to Bravai-Pearson test for the 1990-2013 period, depending on the type of crop, so the correlation coefficients for maize and wheat were higher than in case of the sunflower correlation. The impact of the drought on the vegetation can be confirmed by NDVI, which has very low values in dry years.

\section{References}

Berry, P.M., Rounsevell, M.D.A., Harrisona, P.A., Audsleyc, E. 2006. Assessing the vulnerability of agricultural land use and species to climate change and the role of policy in facilitating adaptation. Environmental Science \& Policy 9, 189-204.

Demuth, S.A. 2009. Learning to live with drought in Europe, World of Science, Quarterly newsletter of the Natural Sciences Sector of UNESCO 7, 18-20.

Dumitrascu, M., 2006. Changes in Oltenia Plain landscape, Romanian Academy Publishing House, $\mathrm{Bu}-$ charest, 228 pp (in Romanian).

Dumitrescu, A. 2012. Spatialization of meteorological and climatic parameters using GIS techniques, $\mathrm{PhD}$ thesis, University of Bucharest, Romania, 233 pp (in Romanian).

Edwards, D. C., McKee, T.B. 1997. Characteristics of 20TH Century drought in the United States at Multiple Time Scales, Master's thesis, $174 \mathrm{pp}$.

Fraser E., Stringer, C.L., 2009. Explaining agricultural collapse: Macro-forces, micro-crises and the emergence of land use vulnerability in southern Romania, Global Environmental Change 19, 45-53;

Gibbs, W. J., and J. V. Maher, 1967: Rainfall Deciles as Drought Indicators. Bureau of Meteorology Bulletin, No. 48, Commonwealth of Australia, $33 \mathrm{pp}$.

Gitelson, A.A. 2012. Remote estimation of crop gross primary production with Landsat data, Remote Sensing of Environment 121, 404-414.
Gobin A. 2012. Impact of heat and drought stress on arable crop production in Belgium, Natural Hazards Earth System Sciences 12, 1911-1922.

Hayes, M.J., Svoboda, M.D., Wilhite D.A., and Vanyarkho, O.V. 1999. Monitoring the 1996 Drought Using the Standardized Precipitation Index, Bulletin American Meteorological Society 80, 429-438.

Holzkämper, A., Calanca, P. Fuhrer, J. 2011. Analyzing climate effects on agriculture in time and space, Procedia Environmental Sciences 3, 58-62.

Iglesias A., Quiroga, S, Diz, A. 2011. Looking into the future of agriculture in a changing climate, European Review of Agricultural Economics 38-3, 427-447.

IPCC 2014. Climate Change 2014: Impacts, Adaptation, and Vulnerability. Contribution of Working Group II to the Fifth Assessment Report of the Intergovernmental Panel on Climate Change [Field, C.B. and V.R. Barros (eds.)]. Cambridge University Press, Cambridge, United Kingdom and New York, NY, USA.

Julien Y. 2006. Changes in land surface temperatures and NDVI values over Europe between 1982 and 1999, Remote Sensing of Environment 103, 43-55.

Lobell, D.B., Schlenker, W., Costa-Roberts, J. 2011. Climate Trends and Global Crop Production Since 1980, Science 333, 616-620.

Maracchi, G., Sirotenko, O., Bindi, M. 2005, Impacts of Present and Future Climate Variability on Agriculture and Forestry in the Temperate Regions: Europe, Climatic Change 70, 117-135.

Mateescu, E., Alexandru, D. 2010. Management recommendations and options to improve crop systems and yields on south-east Romania in the context of regional climate change scenarios over 2020-2050, Scientific Papers 53, 328-334.

McKee, T. B., Doesken, N.J., Kleist, J. 1993. The relationship of drought frequency and duration to time scales. Preprints, 8th Conference on Applied Climatology, American Meteorological Society, 179-184.

Olesen J. E., Bindi M. 2002. Consequences of climate change for European agricultural productivity, land use and policy, European Journal of Agronomy 16, 239-262.

Ontel, I., Morosanu G. 2014. Assessing drought severity and its impact on vegetation within Oltenia Plain using NDVI from MODIS (2000-2010), Riscuri si Catastrofe 14, 21-30.

Paltineanu Cr., Mihailescu, Fl.I, Seceleanu, I., Dragota, C., Vasenciuc, F. 2007. Aridity, drought, evapotranspiration and water requirements of crops in Romania, Ovidius University Press, Constanta, Romania, 319 pp (in Romanian).

Paltineanu, Cr., Mihailescu, I.F., Prefac, Z., Dragota, C., Vasenciuc, F., Claudia, N. 2008. Combining the standardized precipitation index and climatic wa- 
ter deficit in characterizing droughts: a case study in Romania, Theoretical and Applied Climatology 97, 219-233;

Palmer, W.C. 1965. Meteorological droughts. U.S. Department of Commerce Weather Bureau Research Paper 45. U.S. Department of Commerce, Washington, DC, $58 \mathrm{pp}$

Palmer W.C. 1968. Keeping track of crop moisture conditions, nationwide: the new crop moisture index. Weatherwise 21, 156-161.

Parry M.L., Rosenzweig, C., Iglesias, A., Livermore, M., Fischer, G. 2004. Effects of climate change on global food production under SRES emissions and socio-economic scenarios, Global Environmental Change 14, 53-67.

Potop V., 2011. Evolution of drought severity and its impact on corn in the Republic of Moldova, Theor Appl Climatol 105, 469-483.

Pravalie, R. Peptenatu, D., Sirodoev, I. 2013. The impact of climate change on the dynamics of agricultural systems in south-western Romania, Carpathian Journal of Earth and Environmental Sciences 8, 175-186.

Rounsevell, M.D.A., Ewert, F., Reginster, I., Leemans, R., Carter, T.R. 2005. Future scenarios of European agricultural land use II. Projecting changes in cropland and grassland, Agriculture, Ecosystems and Environment 107, 117-135.

Rouse, J. W., Haas, R.H., Schell, J.A., Deering, D.W. 1974. Monitoring vegetation systems in the Great Plains with ERTS, NASA SP-351, Third ERTS-1 Symposium NASA, 1. 309-317.
Sandu, I., Mateescu, E., Vatamanu, V.V. 2010. Climate change and its effects on agriculture in Romania, Sitech Publishing House, Craiova, Romania, 406 pp (in Romanian).

Shahabfar, A., Eitzinger, J. 2013. Spatio-Temporal Analysis of Droughts in Semi-Arid Regions by Using Meteorological Drought Indices, Atmosphere 4, 94-112.

Sonnenschein R., Kuemmerle, T., Udelhoven, T., Stellmesc, M., Hosterta, P. 2011. Differences in Landsatbased trend analyses in drylands due to the choice of vegetation estimate, Remote Sensing of Environment 115, 1408-1420.

Stringer, L. Harris, A. 2013. Land degradation in Dolj county, southern Romania: environmental changes, impacts and responses, Land degradation \& development 25, 17-28.

Thorn, H.C.S. 1966. Some Methods of Climatological Analysis. WMO Technical Note Number 81, Secretariat of the World Meteorological Organization, Geneva, Switzerland, $53 \mathrm{pp}$.

Vlăduţ, A., 2010. Ecoclimatic Indexes within the Oltenia Plain. Forum geografic IX-9, 49-56.

Vlăduț, A. Onțel, I., 2013. Summer air temperature variability and trends within Oltenia Plain, Journal of the Geographical Institute "Jovan Cvijic" SASA 63, 371-381.

Internet 1: http://www.eea.europa.eu

Internet 2: http://drought.unl.edu/MonitoringTools/ DownloadableSPIProgram.aspx

Internet 3: http://earthexplorer.usgs.gov/

Internet 4: http://earthobservatory.nasa.gov/ 